\title{
EFFECT OF HYDROXYBENZOPHENONE DERIVATIVES ON THE PHOTOFADING OF SOME DYES
}

\author{
By Hironori Oda \\ (Department of Home Economics, Nagoya Women's University, \\ 3-40, Shioji, Mizuho-ku, Nagoya, 467 Japan.)
}

\begin{abstract}
Nickel salt of 2-hydroxy-4-methoxybenzophenone-5-sulfonic acid (MS-Ni) and its derivative (DS-Ni), benzophenone type UV absorber containing singlet oxygen quenching group, have been synthesized and its effects were examined on the photofading of some dyes in solution and on a solid with a UV irradiation. The rates of photofading of indigoid dye (C.I. Vat Blue 1), anthraquinonoid dye (C.I. Disperse Red 15) and azo dye (C.I. Acid Orange 20) were remarkably retarded in the presence of MS-Ni or DS-Ni not only in solution but also in a solid state, but that of Eosine (C.I. Acid Red 87) on a solid was suppressed scarcely. The effects of added Nickel p-toluenesulfonate and 2,6-di-t-butylphenol on the photo-stability of dyes were also examined.
\end{abstract}

\section{Introduction}

The ability of dyed polymers to withstand prolonged sunlight exposure without fading or undergoing physical deterioration is determined largely by the photochemical characteristics of the absorbing dyestuff itself. There are many different reaction pathways open to the lightexcited dye molecule, such as ionization, dissociation into free radicals, oxidation, reduction, isomerization, etc. The light-induced fading of dyes in the presence of air usually entails oxidation, and such photo-oxidation reactions may involve oxygen free radicals, singlet oxygen or superoxide ion ${ }^{1)}$. Auto-oxidation reactions of dyes are generally considered to occur on exposure to UV radiation and are retarded by the addition of UV absobers or radical scavengers such as hindered phenols ${ }^{1}$.

The contribution of singlet oxygen to the photofading of dyes has been also examined recently. For example, it has been reported that arylazonaphthols, indigo, quinophthalone, aminoanthraquinones, triphenylmethanes and acylamidostilbenes undergo self-sensitized or dyesensitized photo-oxidation in solution ${ }^{2-3)}$. The rates of photofading of these dyes are suppressed by using an efficient singlet oxygen quencher. However, some problems have remained to be solved in use of the quenchers known today; e.g. instability to light (carotenes) ${ }^{4}$ ), intrinsic color (extensive conjugated systems and nickel dialkyl dithiocarbamates $)^{4)}$, tendency to induce radicals $(\mathrm{DABCO})^{5)}$ and poor quenching efficiency in the adsorbed state.

In previous papers ${ }^{6-7)}$, it has been investigated quenching groups as a means of improving the light fastness of certain dyes in solution and in solid state. It was found that some dyes containing nickel sulfonate as an intramolecular singlet oxygen quenching group show an enhanced photochemical stability towards visible light.

In this paper, the effect of benzophenone type UV absorbers containing nickel sulfonate quenching groups on the photofading of some dyes was examined in UV irradiation.

\section{Experimental}

\subsection{Materials}

The following dyes and UV absorbers were used: Eosine (C.I. Acid Red 87) (dye 1; $\lambda_{\max } 516 \mathrm{~nm}$ ) Indigo (C.I. Vat Blue 1) (dye $2 ; \lambda_{\max } 600 \mathrm{~nm}$ ) 1-Amino-4-hydroxyanthraquinone (C.I. Disperse Red 15) (dye 3; $\lambda_{\max } 525,560 \mathrm{~nm}$ ) 
Orange I (C.I. Acid Orange 20 (dye 4; $\lambda_{\max }$ $474 \mathrm{~nm})$

Sodium 2-hydroxy-4-methoxybenzophenone-5sulfonate (MS; $\lambda_{\max } 285,320 \mathrm{~nm}$ )

Sodium 2,2'-dihydroxy-4,4'-dimethoxybenzophenone-5-sulfonate (DS; $\lambda_{\max } 284,332 \mathrm{~nm}$ )

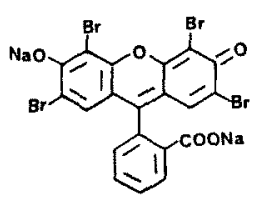

Dye 1

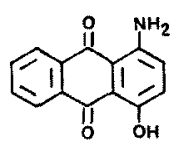

Dye 3

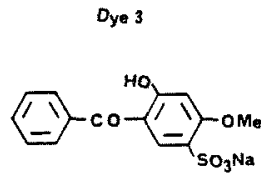

MS

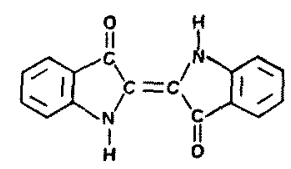

Dye 2
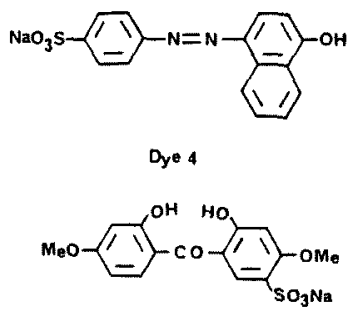

os
Dyes 2-4 were obtained from a commercial source and were further purified by Soxhlet extraction and recrystallization. MS and DS were commercial products, while the nickel salts of MS (MS-Ni; $\lambda_{\max } 285,320 \mathrm{~nm}$ ) and DS (DS-Ni; $\lambda_{\max } 284$, $332 \mathrm{~nm}$ ) were formed with nickel(II) chloride in water, and purified by repeated recrystallization from water. The nickel salt of p-toluenesulfonic acid (NTS; $\lambda_{\max } 233 \mathrm{~nm}$ ) was prepared and purified as described previously ${ }^{6)}$. Dye 1 and 2,6-di$t$-butylphenol (HP) were commercial reagents (Wako Pure Chemical Ind. Co., guarenteed reagent).

\subsection{Procedures for Photofading of Dyes in \\ Solution}

An air-saturated solution of dye $1\left(2 \times 10^{-5} \mathrm{~mol} /\right.$ 1) in $300 \mathrm{ml}$ of acetonitrile-dimethylsulfoxide (DMSO) $(1: 2 \mathrm{vol} . / \mathrm{vol}$.) with or without the additive $\left(1 \times 10^{-3}\right.$ or $\left.2 \times 10^{-3} \mathrm{~mol} / \mathrm{l}\right)$ such as DS, DS-Ni, NTS or HP was placed in a $300 \mathrm{ml}$ flask equipped with a thermometer, condenser and magnetic stirrer, and then irradiated at $27-30^{\circ} \mathrm{C}$ with internal high-pressure mercury lamp (Ushio Electric Inc., UM-102 type).

The absorption spectra of the solutions were measured before and after irradiation using a Shimadzu recording spectrophotometer (UV-180 type) and relative conversions were determined at the absorption maximum of dye 1 .

Similarly the solutions of dyes $2-4\left(5 \times 10^{-5}\right.$ $\mathrm{mol} / \mathrm{l})$ in $300 \mathrm{ml}$ of acetonitrile-DMSO with or without the additive $\left(2.5 \times 10^{-4}, 5 \times 10^{-4}\right.$ or $1 \times 10^{-3}$ $\mathrm{mol} / \mathrm{l}$ ) were irradiated and the photofading was traced. The rates of acetonitrile to DMSO (vol.t) vol.) were $1: 1$ in case of dye 2 , while 1:2 in case of dye 3 and 4.

\subsection{Photofading of Dyes on Silica Gel}

A solution of dye $1\left(6 \times 10^{-6} \mathrm{~mol}\right)$ in aqueous DMSO $(10 \mathrm{ml})$ with or without the additive $\left(6 \times 10^{-5}\right.$ or $\left.1.2 \times 10^{-4} \mathrm{~mol}\right)$ such as MS, MS-Nit DS, DS-Ni, NTS or HP was prepared. Portion of the solutions $(20 \mu 1)$ was spotted on silica gel thin-layer chromatoplate using microsyringe, and dried. The plates were held at a distance of approximately $5 \mathrm{~cm}$ from the light source, and exposed to light $(\lambda>300 \mathrm{~nm})$ in air.

The apparatus was kept at $30 \pm 2^{\circ} \mathrm{C}$. After irradiation for 1 hour, the plates were developed with acetone-chloroform-methanol $(16: 8: 3$ by volume). The concentration of the unchanged dye was determined by using Shimadzu thin layer chromatoscanner (CS-920 type). The percentage conversion was calculated by comparison with unirradiated dye.

A similar procedure was also used for dyes $2-4$.

\section{Results and Discussion}

\subsection{Effect of Various Additives on the Photo- fading of Dyes}

Some dyes containing nickel sulfonate as an intramolecular singlet oxygen quenching group showed an enhanced photochemical stability towards visible light, but little resistance to photofading in UV light. Then, it is of interest to prepare the singlet oxygen quencher containing functional groups capable of absorbing UV light, because it may provide more marked improvements in the light fastness properties of dyes than do conventional quenchers in solar radiation.

In previous study ${ }^{8}$, stilbene-fluorescent dye containing nickel sulfonate quenching groups has been investigated as a means of improving light fastness, but afforded unexpected acceleration of photofading in some dyes with unfiltered radiation $(\lambda>300 \mathrm{~nm})$. With UV absorbers, MS or DS, instead of stilbene-fluorescent dye as a material absorbing UV light, the protecting effect of the 
nickel salts, MS-Ni or DS-Ni, against photofading of some dyes was examined by comparison with the use of NTS, a good singlet oxygen quencher, or HP, a good free-radical scavenger, in solution and solid state.

Solutions of dye 1 in acetonitrile-DMSO faded in air on exposure to unfiltered radiation $(\lambda>300$ nm) from $100 \mathrm{~W}$ high-pressure mercury lamp. The addition of HP in the photofading system afforded little protection against fading. However, the rate of photofading was retarded appreciably in the addition of DS or NTS. Particularly, the use of DS-Ni almost completely suppressed that fading at a half as much amount as DS or NTS (Fig. 1). This behavior suggests that UV absorber containing nickel sulfonate groups might have a significant suppressing effect on the photofading of some dyes.

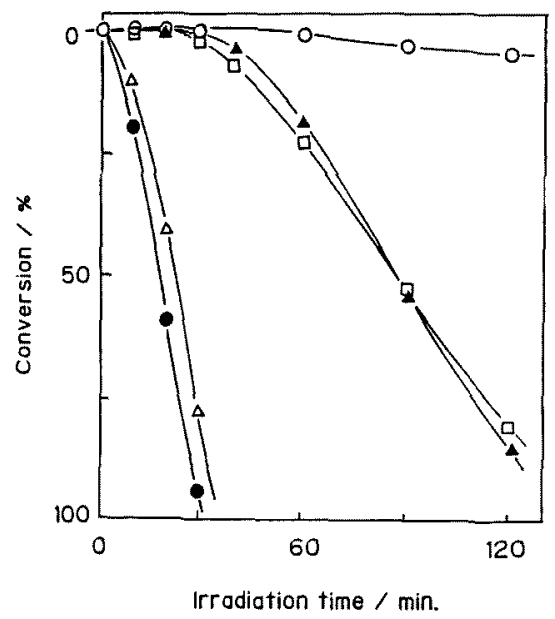

Fig. 1 Effect of various additives on the photofading behavior of dye $1\left(2 \times 10^{-5} \mathrm{~mol} / 1\right)$ in acetonitrile-DMSO (1:2 vol./vol.).

$$
\begin{aligned}
& \text { Additive: - - none, }-\Delta-\text { NTS }\left(2 \times 10^{-3} \text { mol } / 1\right),-\Delta- \\
& \text { HP }\left(2 \times 10^{-3} \mathrm{~mol} / 1\right),-\square-\text { DS }\left(2 \times 10^{-3} \mathrm{~mol} / 1\right), \\
& -\mathrm{O}-\mathrm{DS}-\mathrm{Ni}\left(1 \times 10^{-3} \mathrm{~mol} / 1\right) .
\end{aligned}
$$

In the adsorbed state on silica gel, which perhaps is more relevant to the conditions involved in the practical application of dyes on polymer substrates, influence of these additives on the photostability of dye 1 was examined. These results are shown in Table 1. The rate of photofading of dye 1 in the adsorbed state was not suppressed in the presence of HP at all. The addition of MS, DS
Table 1. Effect of additive on the photofading of dye 1 on silica gel ${ }^{\text {a) }}$.

\begin{tabular}{cccc}
\hline $\begin{array}{c}\text { Run } \\
\text { no }\end{array}$ & Additive & $\begin{array}{c}\text { Additive concn. } \\
\left(\times 10^{-3} \mathrm{~mol} / \mathrm{l}\right)\end{array}$ & $\begin{array}{c}\text { Conversion }{ }^{\mathrm{b})} \\
(\%)\end{array}$ \\
\hline 1 & none & - & 52 \\
2 & $\mathrm{HP}$ & 12 & 52 \\
3 & NTS & 12 & 48 \\
4 & MS & 12 & 44 \\
5 & MS-Ni & 6 & 37 \\
6 & MS-Ni & 12 & 31 \\
7 & DS & 12 & 39 \\
8 & DS-Ni & 6 & 37 \\
9 & DS-Ni & 12 & 30 \\
\hline
\end{tabular}

a) Dye concentration $6 \times 10^{-4} \mathrm{~mol} / 1$, Irradiation time $1 \mathrm{~h}$.

b) Developing solvent: acetone-chloroform-methanol (16:8:3 by volume)

or NTS also afforded little retardation of the rate of photofading, presumably because of restricted diffusion of the dye and quencher. Similar behaviors were observed also in the cases of MS-Ni or DS-Ni. These incomplete protection may be due to the instability of dye 1 towards visible light.

The influence of additives to the photofading using dye 2 was examined as well as in the case of dye 1. These results are shown in Fig. 2 and Table 2. A solution of dye 2 in acetonitrile-DMSO excessively faded in air on exposure to unfiltered radiation $(\lambda>300 \mathrm{~nm})$, while the addition of DS in the photofading system remarkably retarded

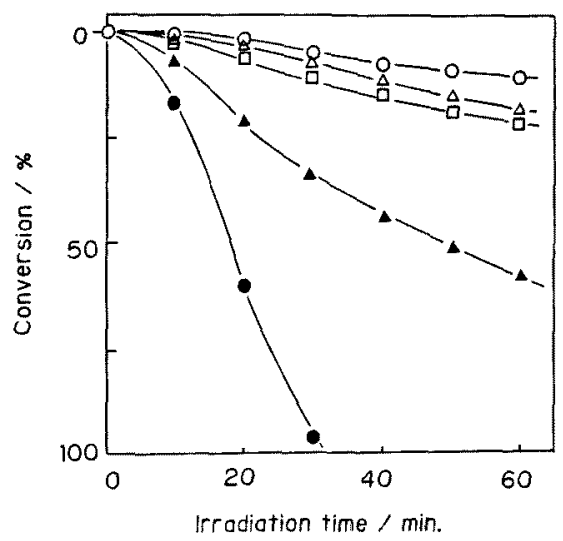

Fig. 2 Effect of various additives on the photofading behavior of dye $2\left(5 \times 10^{-5} \mathrm{~mol} / \mathrm{l}\right)$ in acetonitrile-DMSO (1:1 vol./vol.).

Additive $\left(1 \times 10^{-3}\right.$ mol/1); - - none, $-\Delta-$ MS, $-\Delta-$ $M S-N i,-D-D S,-O-D S-N i$ 
Table 2. Effect of additive on the photofading of dye 2 on silica gel ${ }^{\text {a) }}$.

\begin{tabular}{cccc}
\hline $\begin{array}{c}\text { Run } \\
\text { no }\end{array}$ & Additive & $\begin{array}{c}\text { Additive concn. } \\
\left(\times 10^{-2} \mathrm{~mol} / 1\right)\end{array}$ & $\begin{array}{c}\left.\text { Conversion }{ }^{\mathrm{b}}\right) \\
(\%)\end{array}$ \\
\hline 1 & none & - & 54 \\
2 & NTS & 8 & 36 \\
3 & MS & 8 & 26 \\
4 & MS & 4 & 19 \\
5 & NTS & 4 & 15 \\
6 & MS-Ni & 8 & 16 \\
7 & DS & 8 & 10 \\
\hline
\end{tabular}

a) Dye concentration $4 \times 10^{-3} \mathrm{~mol} / \mathrm{l}$, Irradiation time $15 \mathrm{~h}$.

b) Developing solvent: benzene-acetone ( $9: 1$ vol./vol.)

the fading. The fading of dye 2 in the presence of DS-Ni scarcely occurred in the same manner as dye 1. Such a high degree of protection against the fading of dye 2 was recognized also in the addition of MS-Ni (Fig. 2). Similar protecting effect was observed also in the adsorbed state, and the photofading of dye 2 was retarded noticeably in the presence of NTS or UV absorbers, MS or DS, in contrast to dye 1. The use of a mixture of the case of MS and NTS used gave far more efficient protection against the fading than MS or NTS alone. Further, much higher degree of protection against the photofading of dye 2 was achieved by the addition of MS-Ni or DS-Ni.

These results suggest that the combination of a UV absorber and a singlet oxygen quencher function is very effective for protecting the fading of dyes such as indigo.

\subsection{Photofading of Dyes in the Presence of UV} Absorbers Containing Singlet Oxygen Quenching Groups

The studies with dye 1 and 2 suggested that benzophenone type UV absorbers containing nickel sulfonate quenching groups, MS-Ni or DS-Ni, probably had a significant retarding effect on the rate of photofading of dyes. Therefore, with anocher type of dyes, i.e. dye 3 (anthraquinonoid dye) and dye 4 (azo dye), the effectiveness of these compounds was examined in unfiltered light $(\lambda>300 \mathrm{~nm})$. The influence of some additives on the photostability of dye 3 is summarized in Fig. 3 and Table 3 . The rate of photofading of dye 3 in solution was considerably suppressed by addition of DS, NTS or HP, but scarcely suppressed

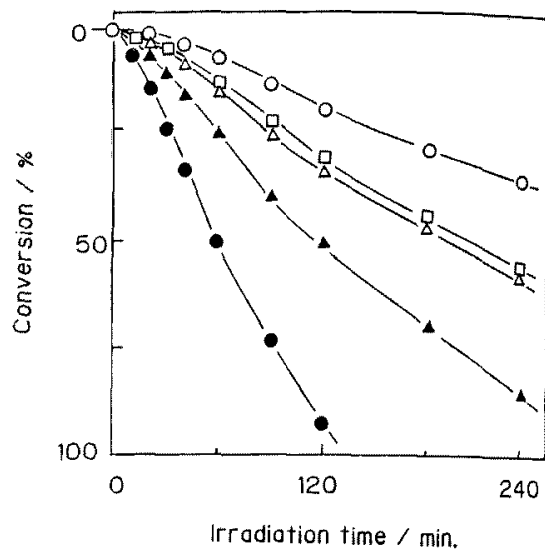

Fig. 3 Effect of various additives on the photo. fading behavior of dye $3\left(5 \times 10^{-5} \mathrm{~mol} / \mathrm{l}\right)$ in acetonitrile-DMSO (1:2 vol. $/ \mathrm{vol}$.$) .$

$$
\begin{gathered}
\text { Additive: - - none, - }- \text { NTS }\left(5 \times 10^{-4} \mathrm{~mol} / 1\right),-\Delta- \\
\text { HP }\left(5 \times 10^{-4} \mathrm{~mol} / 1\right),-\square-\mathrm{DS}\left(5 \times 10^{-4} \mathrm{~mol} / 1\right), \\
-O-\mathrm{DS}-\mathrm{Ni}\left(2.5 \times 10^{-4} \mathrm{~mol} / 1\right) .
\end{gathered}
$$

Table 3. Effect of additive on the photofading of dye 3 on silica gel ${ }^{\text {a) }}$.

\begin{tabular}{cccc}
\hline $\begin{array}{c}\text { Run } \\
\text { no }\end{array}$ & Additive & $\begin{array}{c}\text { Additive concn. } \\
\left(\times 10^{-2} \mathrm{~mol} / \mathrm{l}\right)\end{array}$ & $\begin{array}{c}\text { Conversion } \\
(\%)\end{array}$ \\
\hline 1 & none & - & 75 \\
2 & HP & 8 & 62 \\
3 & NTS & 8 & 61 \\
4 & DS & 8 & 57 \\
5 & DS-Ni & 4 & 36 \\
6 & DS-Ni & 8 & 24 \\
\hline
\end{tabular}

a) Dye concentration $4 \times 10^{-3} \mathrm{~mol} / \mathrm{l}$, Irradiation time $5 \mathrm{~h}$.

b) Developing solvent: benzene-acetone ( $9: 1$ vol//vol.)

in the solid state. However, DS-Ni showed remarkable protecting effect against the fading of dye 3 not only in solution but also in solid state. Similar investigations with dye 4 were also carried out. These results are shown in Fig. 4 and Table 4. When dye 4 on silica gel plate was exposed for 3 hours to unfiltered radiation $(\lambda>300 \mathrm{~nm})$ and air, it showed $96 \%$ conversion, and in the presence of NTS, MS or DS showed $49 \%, 37 \%$ and $34 \%$ conversion, respectively. Moreover, when DS-Ni was added in the photofading system, dye 4 showed only $7 \%$ conversion. Such excellent protecting effect towards fading of dye 4 by DS-Ni was observed also in solution (Fig. 4). The same performance as with DS-Ni can be also achieved 


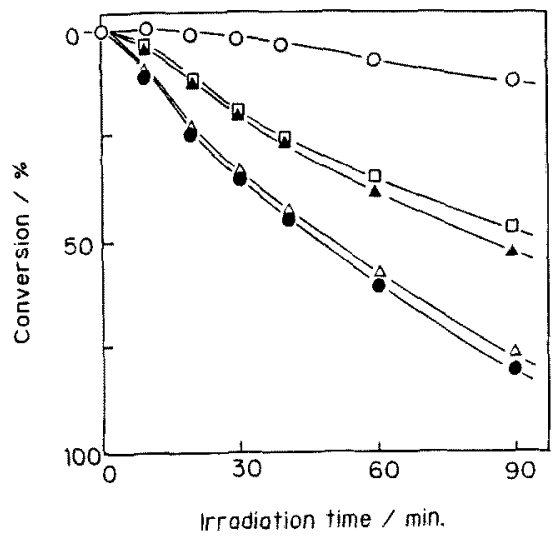

Fig. 4 Effect of various additives on the photofading behavior of dye $4\left(5 \times 10^{-5} \mathrm{~mol} / \mathrm{l}\right)$ in acetonitrile-DMSO $(1: 2 \mathrm{vol} . / \mathrm{vol}$.$) .$

Additive $\left(5 \times 10^{-4}\right.$ nol/1); - - none, $-\Delta-\mathrm{NTS},-\Delta-$ $\mathrm{HP},-\square-D S,-\mathrm{O}-\mathrm{DS}-\mathrm{N} \mathrm{i}$.

Table 4. Effect of additive on the photofading of dye 4 on silica gel ${ }^{\text {a) }}$.

\begin{tabular}{cccc}
\hline $\begin{array}{c}\text { Run } \\
\text { no }\end{array}$ & Additive & $\begin{array}{c}\text { Additive concn. } \\
\left(\times 10^{-2} \mathrm{~mol} / \mathrm{l}\right)\end{array}$ & $\begin{array}{c}\text { Conversion } \mathrm{b}) \\
(\%)\end{array}$ \\
\hline 1 & none & - & 96 \\
2 & HP & 8 & 86 \\
3 & NTS & 8 & 49 \\
4 & MS & 8 & 37 \\
5 & MS-Ni & 4 & 15 \\
6 & DS & 8 & 34 \\
7 & DS-Ni & 4 & 13 \\
8 & DS-Ni & 8 & 7 \\
\hline
\end{tabular}

a) Dye concentration $4 \times 10^{-3} \mathrm{~mol} / 1$, Irradiation time $3 \mathrm{~h}$.

b) Developing solvent: 1-butanol-ethanol-28\%ammonia/water-water $(5: 2: 2: 1$ by volume). by using MS-Ni (see Table 4). On the other hand, HP had little influence on the rate of photofading in both solution and solid state.

These results indicate that nickel salt of 2hydroxy-4-methoxybenzophenone-5-sulfonic acid, MS-Ni, or its derivative, DS-Ni, can be applied as effective stabilizers against fading of dyes, while the situation of fibers and resin materials is expected to be more complicated owing to interactions between dye and substrate.

\section{Acknowledgement}

The author wishes to thank professor Teijiro Kitao of Osaka Prefectural University for his valuable discussions and helpful suggestions.

\section{References}

1) T. Akamatsu and T. Hirashima, "Utilization of Photochemistry", (K. Tokumaru, Ed.), Kyoritsu-shuppan, p 143 (1978).

2) H. Oda, N. Kuramoto and T. Kitao, J. Soc. Dyers Colourists, 97, 467 (1981).

3) N. Kuramoto and T. Kitao, Dyes and Pigments, 3, 49 (1982).

4) H. H. Wasserman and R.W. Murray, "Singlet Oxygen", (H. H. Wasserman, Ed.), Academic Press, New York, p 139 (1979).

5) J. Griffiths and C. Hawkins, J. Appl. Chem. Biotechnol., 27, 558 (1977).

6) H. Oda and T. Kitao, J. Soc. Dyers Colourists, 101,177 (1985).

7) H. Oda and T. Kitao, J. Soc. Dyers Colourists, 102, 305 (1986).

8) H. Oda and T. Kitao, Sen-i Gakkaishi, 42, T-102 (1986).

染料の光退色に及ぼすヒドロキシベンゾフェノン誘導体の効果

\section{名古屋女子大学家政学部織田博 則}

全照射下 $(\lambda>300 \mathrm{~nm})$ におりる染料の勔光性改善を 目的として，可視光照射下 $(\lambda>400 \mathrm{~nm})$ において顕著 な染料の光安定化をるたらすスルホン酸の二ッケル塩を ベンソフェノン系紫外線吸収剂の分子内に導入した化合 物，2-七ドロキシー4-メトキシベンゾフェノンー5-スル ホン酸のニッケル塩 $(\mathrm{MS}-\mathrm{Ni}$ ) 扰よびその誘導体 (DS -Ni), を合成し，その添加効果をC.I. Acid Red 87, C.I. Vat Blue 1, C.I. Disperse Red 15 およびC. 1. Acid Orange 20 を用いて溶液中と固相上で検討し た。また同時に一重項酸素クょンチャーとして知られる pートルエンスルホン酸のニッケル塩 (NTS)や自動酸化 防止剂である 2,6ージーtーブチルフェノール(HP)に拈い ても同様な效果を検討した。その結果HPはさは上染料 の耐光性改善には有効ではなかったが，NTSや紫外線吸 収剖の添加の采ではかなりの退色の抑制効果がみられた。 特に紫外線吸収剂の分子内へスルホン酸のニッケル塩在 導入したMS-Ni P DS-Ni の添加の系では溶液中のみな らず固相上に扣いても非常に顕著な退色の排制効果がみ とめら扎た。 